\title{
Biochemical mechanisms of salinity tolerance in new promising salt tolerant cereal, tritipyrum (TriticumDurum $\times$ Thinopyrum Bessarabicum)
}

\author{
Maryam Kamyab $^{1}$, Mohammad Kafi*1 ${ }^{1}$, Hossein Shahsavand Hassani ${ }^{2}$, Morteza Goldani ${ }^{1}$, Farhad \\ Shokouhifar ${ }^{3}$
}

\author{
${ }^{1}$ Department of Agronomy and Crop Breeding, Ferdowsi University of Mashhad, Iran \\ ${ }^{2}$ Department of Agronomy and Plant Breeding, College of Agriculture, Shiraz University, Iran \\ ${ }^{3}$ Research Institute for Plant Sciences, Ferdowsi University, Mashhad, Iran
}

*Corresponding author: m.kafi@um.ac.ir

\begin{abstract}
Mechanisms of salt tolerance in tritipyrum, a promising achievement of breeding programs against the deleterious effects of salinity stress, have not been fully explored. Therefore, we conducted a greenhouse experiment with four tritipyrum lines and one wheat cultivar under four salinity levels $(0,60,120$ and $180 \mathrm{mM} \mathrm{NaCl})$, in hydroponic condition. Sampling for physiological traits was conducted in 48 hours, one week and one month after exposure to salinity treatment. The results showed that tritipyrum had more chlorophyll pigments and carotenoid than wheat. Furthermore, concentration changes of proline and carbohydrate was more prominent in tritipyrum than in wheat; superoxide dismutase and catalase as well as peroxidase and ascorbate peroxidase activity were lower in Az/b and $(\mathrm{Ka} / \mathrm{b})^{*}(\mathrm{Cr} / \mathrm{b}), \mathrm{F}_{6}$ than in $\mathrm{Cr} / \mathrm{b}$ and wheat; lower malondialdehyde in Az/b and $(\mathrm{Ka} / \mathrm{b}) *(\mathrm{Cr} / \mathrm{b}), \mathrm{F}_{6}$ indicated higher salinity tolerance of these hybrids compared with wheat and $\mathrm{Cr} / \mathrm{b}$; it was also found that different genotypes used various defense mechanisms to adapt themselves to salinity. Other defense mechanisms such as developed photosynthetic machinery, better activity of non-enzymatic antioxidant systems and higher accumulation of compatible solutes can be more effective than antioxidant enzymes in higher salt tolerance of tritipyrum lines. Our results indicate that non-enzymatic defense systems are more important than enzymatic ones in tolerating salinity stress in tritipyrum lines. Furthermore, in comparison with wheat, higher salinity tolerance of tritipyrum lines, especially Az/b, can make them suitable for the improvement of salinity tolerance of common wheat by breeding programs.
\end{abstract}

Keywords: antioxidant, carbohydrate, chlorophyll, proline, malondialdehyde.

Abbreviations: APX_Ascorbate peroxidase; CAT_Catalase; Chl a_ Chlorophyll $a$; Chl b_Chlorophyll $b$; EDTA_ Ethylenediaminetetraacetic acid; MDA_Malondialdehyde; NBT_Nitro-blue tetrazolium; PCA_Principal component analysis; POX_Peroxidase; ROS_Reactive oxygen species; SOD_Superoxide dismutase; TSC_Total soluble carbohydrate.

\section{Introduction}

Salinity stress is a major limitation factor which affects the growth, development and productivity of plants worldwide (Zhu, 2001) and has been increasingly intensified as a result of poor agriculture management (Munns and Tester, 2008). Various strategies are suggested to cope with salinity problem. One of the strategies is the improvement of crop salt tolerance which the use of tritipyrum (a hybrid of wheat and Th. Bessarabicum) as a new synthetic amphiploid and salt tolerant cereal is a promissing approach. It has $\mathrm{E}^{\mathrm{b}}$ genome instead of $\mathrm{D}$ genome present in hexaploid wheat and shows high tolerance to salinity. It is suggested that tritipyrum is capable of being used as a new cereal in saline soils (King et al., 1997). However, its salinity resistance mechanisms are still unclear.

Some mechanisms such as the development of photosynthesis system and pigments (Hasegawa et al., 2000; Ahmad et al., 2012; Ashraf and Harris, 2013), osmotic adjustment (Sairam and Tyagi, 2004), and the use of different enzymatic and non-enzymatic antioxidant systems (Yokoi et al., 2002; Meloni et al., 2003) have been adopted in a wide range by plants to attenuate deleterious effects of salinity. Chlorophyll content has been reduced by salinity stress; therefore, it has been suggested as an indicator of salt tolerance in crops (Meloni et al., 2003; Khan et al., 2009). Compatible solutes like proline and carbohydrate involve in osmoregulation and contribute to maintaining turgor, membrane and protein stabilization, scavenging hydroxyl radicals and storing energy and nitrogen within the cell during salinity stress (Ashraf and Harris, 2004; Matysik et al., 2002; Kishor et al., 2005; Wang et al., 2007). However, some researchers reported that proline and carbohydrate accumulation is not a plant response to salt tolerance and it may be a sign of salt stress damage or decreased export of supplied carbohydrate by photosynthesis (de Lacerda et al., 2003; Parida and Das, 2005). Moreover, accumulation of reactive oxygen species (ROS) is a biochemical reaction to salinity stress and leads to oxidative damage to biomolecules such as membrane lipids, proteins and nucleic acids; thus, defense against ROS is necessary for plants to tolerate salt stress (Mittler, 2002; Apel and Hirt, 2004). To mitigate injurious effects of ROS, plants have developed non- 
enzymatic and enzymatic antioxidant systems (Ahmad et al., 2010). Carotenoids are lipid-soluble and non-enzymatic antioxidants that protect cells and tissues by quenching ROS (Sairam et al., 2002). SOD is an initial step of cellular defense against ROS and has a key role in converting $\mathrm{O}^{2-}$ to $\mathrm{O}_{2}$ and $\mathrm{H}_{2} \mathrm{O}_{2}$ by its enzymatic action (Sharma et al., 2012). $\mathrm{H}_{2} \mathrm{O}_{2}$ produced by SOD activity is still noxious and should be detoxified by other enzymes such as catalase, peroxidase and ascorbate peroxidase (Apel and Hirt, 2004, Ahmad et al., 2010). ROS induces lipid peroxidation and leads to membrane descent. Therefore, malondialdehyde (MDA), as a product of lipid peroxidation, has been regarded as an oxidative damage indicator during salinity stress (Demiral and Türkan, 2005).

The question raised is whether responses and tolerance mechanisms of tritipyrum lines against salinity stress are similar to those of common wheat? Therefore, the present study is an attempt to determine and compare the effects of salinity stress on photosynthetic pigments like chlorophyll and carotenoids, compatible solutes, the behavior of enzymatic and non-enzymatic antioxidant defense system and the lipid peroxidation between tritipyrum lines and common wheat as well as among tritipyrum lines themselves. Identification of different responses of these genotypes to salinity stress can help describethe possible involvement of physiological and biochemical mechanisms in salt stress tolerance of tritipyrum genotypes.

\section{Results}

\section{Effect of salinity stress on photosynthetic pigments}

Genotypes were significantly different in chlorophyll $a$ and $b$ and carotenoid content. These pigments and their changes were lower in wheat cultivar Bam than in tritipyrum lines (Table 1). In all genotypes, an age-dependent and salinityinduced response was observed to the content of chlorophyll (Table 1).

Generally, in tritipyrum lines with salinity tolerance, Chla was higher at $60 \mathrm{mM} \mathrm{NaCl}$ than the control at all salinity levels and growth stages (Table 1). The content of Chlb was lower than that of Chla in all genotypes (Table 1). Our results revealed that salinity stress affected Chl $b$ more than Chla. In all genotypes, carotenoid pigment increased by salinity stress (Table 1).Cr/b showed the least changes in carotenoid concentration at different salinity levels. The most changes in carotenoid concentration was also observed in $(\mathrm{Ka} / \mathrm{b}) *(\mathrm{Cr} / \mathrm{b})$, $\mathrm{F}_{6}$ (Table 1).

\section{The status of genotypes' Compatible solutes under salinity}

The amount of total soluble carbohydrate (TSC) and proline was affected by different salinity levels and stages. Significant differences were observed between tritipyrum lines and wheat in terms of compatible solutes (Table 1). In tritipyrum lines, TSC increased significantly at $60 \mathrm{mM}$ $\mathrm{NaCl}$ compared with control and, then decreased with an increase in salinity to $180 \mathrm{mM} \mathrm{NaCl}$. However, in wheat cultivar Bam, TSC decreased with an increase in salinity at $180 \mathrm{mM} \mathrm{NaCl}$ (Table 1). Exposure to salt stress led to an increase in proline concentration. Increasing salinity up to $180 \mathrm{mM}$ raised proline content in tritipyrum lines more than in wheat cultivar (Table 1).

An age-dependent increase in carbohydrate and proline concentration was observed in all used genotypes. In general, increasing salinity and age caused higher increase in compatible solutes of tritipyrum lines compared with that of wheat cultivar Bam.

\section{Enzymes activity and salinity stress}

In all used genotypes, both salt stress and growth stages reduced SOD activity in comparison to control (Fig. 1). All genotypes showed a reduction in SOD activity at different salinity levels and growth stages. All genotypes showed the highest SOD activity at control condition and the lowest one at the highest salinity level (Fig. 1).Generally, the highest amount of SOD activity was observed in Bam and $\mathrm{Cr} / \mathrm{b}$ and the lowest one in $\mathrm{Az} / \mathrm{b}$ and $(\mathrm{Ka} / \mathrm{b}) *(\mathrm{Cr} / \mathrm{b}), \mathrm{F}_{6}$.

The results showed that CAT activity depends on both the age of genotypes and the salinity level. The trend of CAT activity in Az/b was similar to that in $(\mathrm{Ka} / \mathrm{b}) *(\mathrm{Cr} / \mathrm{b}), \mathrm{F}_{6}$ (Fig. 2 ). They showed the highest CAT activity at $60 \mathrm{mM}$ and the lowest one at $180 \mathrm{mM}$ in $48 \mathrm{~h}$, one week and one month after salinity treatment (Fig. 1).At $180 \mathrm{mM} \mathrm{NaCl}$, variable levels of CAT activity in $(\mathrm{Ka} / \mathrm{b})^{*}(\mathrm{Cr} / \mathrm{b}), \mathrm{F}_{6}$ were more clear than that of $\mathrm{Az} / \mathrm{b}$ at different salinity levels, but they were lower in $(\mathrm{Ka} / \mathrm{b})^{*}(\mathrm{Cr} / \mathrm{b}), \mathrm{F} 6$ than $\mathrm{Az} / \mathrm{b}$ at $60 \mathrm{mM} \mathrm{NaCl}$ (Fig. 1). Az/b showed higher CAT activity than $(\mathrm{Ka} / \mathrm{b})^{*}(\mathrm{Cr} / \mathrm{b}), \mathrm{F}_{6}$ at all salinity levels and growth stages. There was an agedependent increase in CAT activity of these lines and it was higher in Az/b than in $(\mathrm{Ka} / \mathrm{b}) *(\mathrm{Cr} / \mathrm{b}), \mathrm{F} 6$ (Fig. 1). A rise in both age and salinity caused a progressive increase in CAT activity in wheat cultivar Bam (Fig. 1). In contrast with $\mathrm{Cr} / \mathrm{b}$, CAT activity in wheat cultivar Bam increased markedly with an increase in salinity compared to control condition (Fig. 1).Interestingly, wheat cultivar Bam recorded significantly higher CAT activity in comparison with tritipyrum lines.

$\mathrm{Az} / \mathrm{b}$ and $(\mathrm{Ka} / \mathrm{b})^{*}(\mathrm{Cr} / \mathrm{b}), \mathrm{F}_{4}$ showed similar pattern of POX activity change during different growth stages and salinity levels (Fig. 2). The POX activity of Az/b was higher than that of $(\mathrm{Ka} / \mathrm{b}) *(\mathrm{Cr} / \mathrm{b}), \mathrm{F}_{6}$ at all stages (Fig. 2).

Bam wheat cultivar represented significantly lower POX activity than $\mathrm{Cr} / \mathrm{b}$, while reduction in POX activity during salinity stress levels was almost similar in both of them (Fig. 2). Generally, the ranges of changes in POX activity during salinity stress were lower in tritipyrum lines than in wheat cultivar Bam.

Both age and salinity stress changed APX activity of all genotypes (Fig. 2). Az/b and $(\mathrm{Ka} / \mathrm{b}) *(\mathrm{Cr} / \mathrm{b}), \mathrm{F}_{6}$ showed the lowest APX activity at $60 \mathrm{mM} \mathrm{NaCl}$ treatment; however, they had the highest APX activity at the highest salinity level (180 $\mathrm{mM} \mathrm{NaCl}$ ) (Fig. 2). An enhancement in APX activity of Az/b and $(\mathrm{Ka} / \mathrm{b})^{*}(\mathrm{Cr} / \mathrm{b}), \mathrm{F}_{6}$ was observed one month after the salinity treatment at $180 \mathrm{mM}$ (Fig. 2). APX activity in Bam and $\mathrm{Cr} / \mathrm{b}$ increased linearly and reached to maximum level in $180 \mathrm{mM} \mathrm{NaCl}$ treatment (Fig. 2).

One month of salt treatment caused a significant increase in APX activity in wheat cultivar Bam and $\mathrm{Cr} / \mathrm{b}$ at $180 \mathrm{mM}$ compared with $48 \mathrm{~h}$ of salt treatment (Fig. 2).

\section{Malondialdehyde (MDA) changes in genotypes in salinity condition}

The amount of MDA of all genotypes progressively increased with their growth and development and the increased salinity level (Fig. 3). Genotypes $(\mathrm{Ka} / \mathrm{b})^{*}(\mathrm{Cr} / \mathrm{b}), \mathrm{F}_{6}$, and $\mathrm{Az} / \mathrm{b}$ revealed the lower MDA content and better membrane integrity at $60 \mathrm{mM} \mathrm{NaCl}$. Then, the MDA increased with an increase in salinity and reached to its maximum amount at $180 \mathrm{mM} \mathrm{NaCl}$. This trend was kept with an increase at the age of these genotypes as well (Fig. 3). 
Table 1. Effect of different salinity levels $(0,60,120$ and $180 \mathrm{mM} \mathrm{NaCl})$ on physiological and biochemical traits of tritipyrum lines and wheat cultivar Bam measured after $48 \mathrm{~h}$, one week and one month after salinity stress initiation. Data are mean $\pm \mathrm{SE}(P \leq 0.05)$.

\begin{tabular}{|c|c|c|c|c|c|c|c|c|c|c|c|c|c|}
\hline \multicolumn{4}{|c|}{ Growth stag } & \multicolumn{2}{|c|}{$48 \mathrm{~h}$ after salinity tereatment } & \multicolumn{6}{|c|}{ One week after salinity treatment } & \multicolumn{2}{|c|}{ One month after salinity treatment } \\
\hline \multirow{5}{*}{$\begin{array}{l}\text { Chlorophyll } \\
\text { a content } \\
(\mathrm{mg} / \mathrm{g} \mathrm{FW})\end{array}$} & Salinity levels & 0 & $60 \mathrm{mM}$ & $120 \mathrm{mM}$ & $180 \mathrm{mM}$ & 0 & $60 \mathrm{mM}$ & $120 \mathrm{mM}$ & $180 \mathrm{mM}$ & 0 & $60 \mathrm{mM}$ & $120 \mathrm{mM}$ & $180 \mathrm{mM}$ \\
\hline & $\mathrm{Az} / \mathrm{b}$ & $1.31 \pm 0.036^{\mathrm{gk}}$ & $1.51 \pm 0.029^{\mathrm{bh}}$ & $1.45 \pm 0.053^{\mathrm{ci}}$ & $1.32 \pm 0.036^{\mathrm{fk}}$ & $1.44 \pm 0.039^{\mathrm{cj}}$ & $1.64 \pm 0.026^{\mathrm{ad}}$ & $1.56 \pm 0.036^{\mathrm{ag}}$ & $1.50 \pm 0.028^{\mathrm{bh}}$ & $1.60 \pm 0.037^{\mathrm{ac}}$ & $1.78 \pm 0.026^{\mathrm{a}}$ & $1.73 \pm 0.045^{\mathrm{ab}}$ & $1.68 \pm 0.022^{\mathrm{ac}}$ \\
\hline & $(\mathrm{Ka} / \mathrm{b})^{*}(\mathrm{Cr} / \mathrm{b}), \mathrm{F}_{6}$ & $1.28 \pm 0.026^{\mathrm{hl}}$ & $1.47 \pm 0.041^{\mathrm{bi}}$ & $1.35 \pm 0.020^{\mathrm{ek}}$ & $1.28 \pm 0.063^{\mathrm{hl}}$ & $1.41 \pm 0.025^{\mathrm{dj}}$ & $1.58 \pm 0.037^{\mathrm{af}}$ & $1.55 \pm 0.031^{\mathrm{bh}}$ & $1.44 \pm 0.038^{\mathrm{cj}}$ & $1.57 \pm 0.038^{\mathrm{ag}}$ & $1.80 \pm 0.021^{\mathrm{a}}$ & $1.60 \pm 0.050^{\mathrm{ae}}$ & $1.60 \pm 0.058^{\mathrm{ae}}$ \\
\hline & $\mathrm{Cr} / \mathrm{b}$ & $1.06 \pm 0.021^{\mathrm{hm}}$ & $1.23 \pm 0.037^{\mathrm{cj}}$ & $1.10 \pm 0.026^{\mathrm{gk}}$ & $1.12 \pm 0.033^{\mathrm{fk}}$ & $1.14 \pm 0.030^{\mathrm{ek}}$ & $1.28 \pm 0.034^{\mathrm{bh}}$ & $1.24 \pm 0.025^{\mathrm{ci}}$ & $1.21 \pm 0.045^{\mathrm{cj}}$ & $1.28 \pm 0.052^{\mathrm{bh}}$ & $1.38 \pm 0.014^{\text {af }}$ & $1.31 \pm 0.022^{\mathrm{ch}}$ & $1.29 \pm 0.032^{\mathrm{bh}}$ \\
\hline & Bam & $0.93 \pm 0.051^{\mathrm{nr}}$ & $0.93 \pm 0.039^{\text {or }}$ & $0.84 \pm 0.063^{\mathrm{pr}}$ & $0.72 \pm 0.06^{1 \mathrm{r}}$ & $1.13 \pm 0.072^{\mathrm{ko}}$ & $1.01 \pm 0.054^{\mathrm{mq}}$ & $0.87 \pm 0.10^{\text {or }}$ & $0.76 \pm 0.044^{\mathrm{qr}}$ & $1.43 \pm 0.11^{\mathrm{cj}}$ & $1.23 \pm 0.023^{\mathrm{im}}$ & $1.19 \pm 0.041^{\mathrm{jn}}$ & $1.03 \pm 0.055^{\mathrm{lp}}$ \\
\hline $\mathrm{CV}$ & 19.60 & & & & & & & & & & & & \\
\hline \multirow{4}{*}{$\begin{array}{l}\text { Chlorophyll } \\
\text { b content } \\
\text { (mg/g FW) }\end{array}$} & $\mathrm{Az} / \mathrm{b}$ & $0.34 \pm 0.028^{\mathrm{gk}}$ & $0.41 \pm 0.028^{\text {bh }}$ & $0.42 \pm 0.046^{\text {bh }}$ & $0.36 \pm 0.13^{\mathrm{ek}}$ & $0.40 \pm 0.019^{\mathrm{ci}}$ & $0.45 \pm 0.013^{\text {ah }}$ & $0.45 \pm 0.013^{\text {ah }}$ & $0.43 \pm 0.014^{\mathrm{ah}}$ & $0.45 \pm 0.022^{\text {ah }}$ & $0.51 \pm 0.009^{\mathrm{ad}}$ & $0.51 \pm 0.011^{\mathrm{ad}}$ & $0.48 \pm 0.010^{\mathrm{af}}$ \\
\hline & $(\mathrm{Ka} / \mathrm{b})^{*}(\mathrm{Cr} / \mathrm{b}), \mathrm{F}_{6}$ & $0.42 \pm 0.017^{\mathrm{bh}}$ & $0.46 \pm 0.008^{\text {af }}$ & $0.46 \pm 0.015^{\mathrm{af}}$ & $0.42 \pm 0.032^{\mathrm{bh}}$ & $0.44 \pm 0.009^{\text {ah }}$ & $0.51 \pm 0.024^{\mathrm{ad}}$ & $0.50 \pm 0.020^{\mathrm{ae}}$ & $0.45 \pm 0.008^{\text {ah }}$ & $0.51 \pm 0.023^{\mathrm{ad}}$ & $0.56 \pm 0.008^{\mathrm{a}}$ & $0.51 \pm 0.020^{\mathrm{ac}}$ & $0.53 \pm 0.035^{\mathrm{ac}}$ \\
\hline & $\mathrm{Cr} / \mathrm{b}$ & $0.34 \pm 0.011^{\mathrm{bh}}$ & $0.38 \pm 0.011^{\text {ah }}$ & $0.35 \pm 0.011^{\text {ah }}$ & $0.36 \pm 0.012^{\text {ah }}$ & $0.35 \pm 0.012^{\text {bh }}$ & $0.39 \pm 0.018^{\text {af }}$ & $0.38 \pm 0.011^{\text {ah }}$ & $0.37 \pm 0.008^{\text {ah }}$ & $0.40 \pm 0.016^{\mathrm{af}}$ & $0.46 \pm 0.012^{\mathrm{ab}}$ & $0.41 \pm 0.17^{\mathrm{af}}$ & $0.40 \pm 0.019^{\mathrm{af}}$ \\
\hline & Bam & $0.24 \pm 0.010^{\mathrm{k}}$ & $0.25 \pm 0.014^{\mathrm{jk}}$ & $0.26 \pm 0.006^{\mathrm{jk}}$ & $0.26 \pm 0.006^{\mathrm{jk}}$ & $0.33 \pm 0.054^{\mathrm{hk}}$ & $0.26 \pm 0.031^{\mathrm{jk}}$ & $0.24 \pm 0.006^{\mathrm{k}}$ & $0.27 \pm 0.007^{\mathrm{ik}}$ & $0.40 \pm 0.056^{\mathrm{ci}}$ & $0.36 \pm 0.037^{\mathrm{fk}}$ & $0.38 \pm 0.030^{\mathrm{dj}}$ & $0.27 \pm 0.058^{\mathrm{ik}}$ \\
\hline \multirow[t]{2}{*}{$\mathrm{CV}$} & 22.16 & & & & & & & & & & & & \\
\hline & $\mathrm{Az} / \mathrm{b}$ & $0.38 \pm 0.010^{\mathrm{gm}}$ & $0.43 \pm 0.024^{\mathrm{ci}}$ & $0.45 \pm 0.006^{\mathrm{bi}}$ & $0.46 \pm 0.015^{\mathrm{bi}}$ & $0.39 \pm 0.013^{\mathrm{fl}}$ & $0.47 \pm 0.013^{\text {bh }}$ & $0.48 \pm 0.012^{\mathrm{bg}}$ & $0.49 \pm 0.010^{\mathrm{af}}$ & $0.41 \pm 0.017^{\mathrm{dj}}$ & $0.50 \pm 0.010^{\mathrm{af}}$ & $0.51 \pm 0.15^{\text {ae }}$ & $0.53 \pm 0.021^{\mathrm{ac}}$ \\
\hline Caretonoid & $(\mathrm{Ka} / \mathrm{b}) *(\mathrm{Cr} / \mathrm{b}), \mathrm{F}_{6}$ & $0.28 \pm 0.014^{\mathrm{mq}}$ & $0.36 \pm 0.011^{\text {ip }}$ & $0.36 \pm 0.016^{\mathrm{ho}}$ & $0.37 \pm 0.031^{\mathrm{gm}}$ & $0.36 \pm 0.005^{\mathrm{ho}}$ & $0.45 \pm 0.024^{\mathrm{bi}}$ & $0.46 \pm 0.013^{\mathrm{bi}}$ & $0.49 \pm 0.014^{\mathrm{af}}$ & $0.38 \pm 0.013^{\mathrm{gm}}$ & $0.53 \pm 0.026^{\mathrm{ac}}$ & $0.55 \pm 0.038^{\mathrm{ab}}$ & $0.60 \pm 0.014^{\mathrm{a}}$ \\
\hline \multirow[t]{2}{*}{ (mg/g FW) } & $\mathrm{Cr} / \mathrm{b}$ & $0.44 \pm 0.029^{\mathrm{ek}}$ & $0.40 \pm 0.009^{\text {hn }}$ & $0.41 \pm 0.016^{\mathrm{gm}}$ & $0.43 \pm 0.022^{\mathrm{fl}}$ & $0.45 \pm 0.010^{\mathrm{di}}$ & $0.47 \pm 0.026^{\mathrm{ci}}$ & $0.50 \pm 0.012^{\mathrm{bi}}$ & $0.50 \pm 0.012^{\mathrm{bi}}$ & $0.51 \pm 0.017^{\mathrm{bg}}$ & $0.49 \pm 0.014^{\mathrm{bi}}$ & $0.52 \pm 0.029^{a f}$ & $0.55 \pm 0.014^{\text {ad }}$ \\
\hline & Bam & $0.25 \pm 0.034^{\mathrm{q}}$ & $0.25 \pm 0.034^{\mathrm{pq}}$ & $0.26 \pm 0.012^{\mathrm{oq}}$ & $0.27 \pm 0.010^{\mathrm{mq}}$ & $0.25 \pm 0.020^{\mathrm{q}}$ & $0.26 \pm 0.015^{\mathrm{nq}}$ & $0.28 \pm 0.017^{\mathrm{mq}}$ & $0.31 \pm 0.018^{\mathrm{jq}}$ & $0.27 \pm 0.024^{\mathrm{mq}}$ & $0.30 \pm 0.01^{\mathrm{lq}}$ & $0.31 \pm 0.012^{\mathrm{kq}}$ & $0.37 \pm 0.012^{\mathrm{hn}}$ \\
\hline \multirow[t]{2}{*}{$\mathrm{CV}$} & 23.89 & & & & & & & & & & & & \\
\hline & $\mathrm{Az} / \mathrm{b}$ & $100.73 \pm 4.63^{\text {af }}$ & $109.07 \pm 9.72^{\text {af }}$ & $96.53 \pm 9.45^{\text {af }}$ & $83.33 \pm 10.78^{\text {cf }}$ & $102.87 \pm 11.47^{\mathrm{af}}$ & $113.53 \pm 7.34^{\text {af }}$ & $99.20 \pm 9.67^{\text {af }}$ & $95.40 \pm 4.45^{\text {af }}$ & $114.40 \pm 12.60^{\mathrm{af}}$ & $133.93 \pm 7.90^{\mathrm{ab}}$ & $124.60 \pm 7.44^{\mathrm{ac}}$ & $122.93 \pm 5.39^{\text {ae }}$ \\
\hline Carbohydrate & $(\mathrm{Ka} / \mathrm{b})^{*}(\mathrm{Cr} / \mathrm{b}), \mathrm{F}_{6}$ & $84.40 \pm 4.61^{\mathrm{cf}}$ & $112.67 \pm 5.07^{\mathrm{af}}$ & $99.60 \pm 5.57^{\text {af }}$ & $89.33 \pm 6.91^{\mathrm{cf}}$ & $91.40 \pm 6.76^{\mathrm{cf}}$ & $115.20 \pm 3.58^{\mathrm{af}}$ & $106.13 \pm 5.47^{\mathrm{af}}$ & $94.40 \pm 4.35^{\text {af }}$ & $105.87 \pm 3.97^{\mathrm{af}}$ & $135.53 \pm 5.33^{\mathrm{a}}$ & $114.80 \pm 5.10^{\text {af }}$ & $107.67 \pm 5.04^{\text {af }}$ \\
\hline \multirow[t]{2}{*}{ (mg/g FW) } & $\mathrm{Cr} / \mathrm{b}$ & $77.53 \pm 8.31^{\mathrm{f}}$ & $82.27 \pm 6.68^{\mathrm{df}}$ & $81.93 \pm 6.70^{\text {ef }}$ & $81.53 \pm 5.07^{\mathrm{ef}}$ & $77.93 \pm 6.55^{\mathrm{f}}$ & $89.73 \pm 6.59^{\mathrm{cf}}$ & $86.53 \pm 6.33^{\text {cf }}$ & $80.93 \pm 5.10^{f}$ & $104.40 \pm 7.40^{\mathrm{af}}$ & $123.73 \pm 3.80^{\text {ad }}$ & $102.93 \pm 5.42^{\text {af }}$ & $92.67 \pm 7.51^{\text {bf }}$ \\
\hline & Bam & $75.93 \pm 8.60^{f}$ & $76.67 \pm 7.81^{\mathrm{f}}$ & $76.67 \pm 5.53^{\mathrm{f}}$ & $78.87 \pm 7.45^{\mathrm{f}}$ & $91.40 \pm 6.89^{\mathrm{cf}}$ & $88.73 \pm 5.89^{\mathrm{cf}}$ & $85.53 \pm 8.08^{\mathrm{cf}}$ & $81.33 \pm 6.77^{\mathrm{ef}}$ & $114.07 \pm 10.27^{\mathrm{af}}$ & $102.93 \pm 8.51^{\text {af }}$ & $96.60 \pm 9.88^{\text {af }}$ & $85.53 \pm 5.20^{\mathrm{cf}}$ \\
\hline \multirow[t]{2}{*}{$\mathrm{CV}$} & 19.14 & & & & & & & & & & & & \\
\hline & $\mathrm{Az} / \mathrm{b}$ & $44.54 \pm 4.91^{\text {gr }}$ & $48.96 \pm 5.38^{\mathrm{pr}}$ & $112.65 \pm 4.35^{\mathrm{fk}}$ & $228.96 \pm 23.01^{\mathrm{c}}$ & $43.00 \pm 6.06^{\mathrm{r}}$ & $74.94 \pm 8.86^{\mathrm{jr}}$ & $120.92 \pm 19.01^{\mathrm{ej}}$ & $291.77 \pm 12.78^{\mathrm{b}}$ & $48.68 \pm 3.67^{\mathrm{pr}}$ & $76.48 \pm 10.09^{\mathrm{jr}}$ & $155.46 \pm 11.26^{\mathrm{ef}}$ & $393.81 \pm 12.65^{\mathrm{a}}$ \\
\hline Proline & $(\mathrm{Ka} / \mathrm{b})^{*}(\mathrm{Cr} / \mathrm{b}), \mathrm{F}_{6}$ & $64.74 \pm 4.70^{\mathrm{lr}}$ & $110.44 \pm 8.93^{\mathrm{fl}}$ & $174.51 \pm 5.75^{\mathrm{d}}$ & $251.75 \pm 8.33^{\mathrm{bc}}$ & $67.15 \pm 5.14^{\mathrm{kr}}$ & $97.16 \pm 7.74^{\text {ho }}$ & $99.76 \pm 5.05^{\mathrm{gn}}$ & $227.32 \pm 4.91^{\mathrm{c}}$ & $78.22 \pm 3.90^{\mathrm{jr}}$ & $86.20 \pm 5.58^{\text {ir }}$ & $91.97 \pm 6.78^{\text {iq }}$ & $140.93 \pm 11.05^{\mathrm{dh}}$ \\
\hline \multirow[t]{2}{*}{$(\mathrm{mg} / \mathrm{g} \mathrm{FW})$} & $\mathrm{Cr} / \mathrm{b}$ & $47.91 \pm 8.74^{\mathrm{pr}}$ & $55.41 \pm 3.78^{\mathrm{nr}}$ & $63.68 \pm 3.38^{\mathrm{lr}}$ & $147.47 \pm 5.04^{\mathrm{dg}}$ & $58.68 \pm 3.76^{\mathrm{nr}}$ & $64.65 \pm 4.64^{\mathrm{lr}}$ & $79.46 \pm 8.30^{\mathrm{jr}}$ & $166.91 \pm 9.72^{\mathrm{de}}$ & $49.54 \pm 4.26^{\text {or }}$ & $53.78 \pm 11.55^{\mathrm{nr}}$ & $74.55 \pm 6.36^{\mathrm{jr}}$ & $110.24 \pm 5.96^{\mathrm{fl}}$ \\
\hline & Bam & $52.33 \pm 6.91^{\mathrm{nr}}$ & $48.20 \pm 4.41^{\mathrm{pr}}$ & $60.80 \pm 3.84^{\mathrm{mr}}$ & $55.60 \pm 5.11^{\mathrm{nr}}$ & $53.87 \pm 5.27^{\mathrm{nr}}$ & $61.76 \pm 4.25^{\mathrm{mr}}$ & $78.59 \pm 2.41^{\mathrm{jr}}$ & $108.22 \pm 13.59^{\mathrm{fm}}$ & $72.53 \pm 7.37^{\mathrm{kr}}$ & $76.77 \pm 3.041^{\mathrm{jr}}$ & $93.60 \pm 6.80^{\text {hp }}$ & $130.73 \pm 5.41^{\mathrm{di}}$ \\
\hline $\mathrm{CV}$ & 69.12 & & & & & & & & & & & & \\
\hline
\end{tabular}



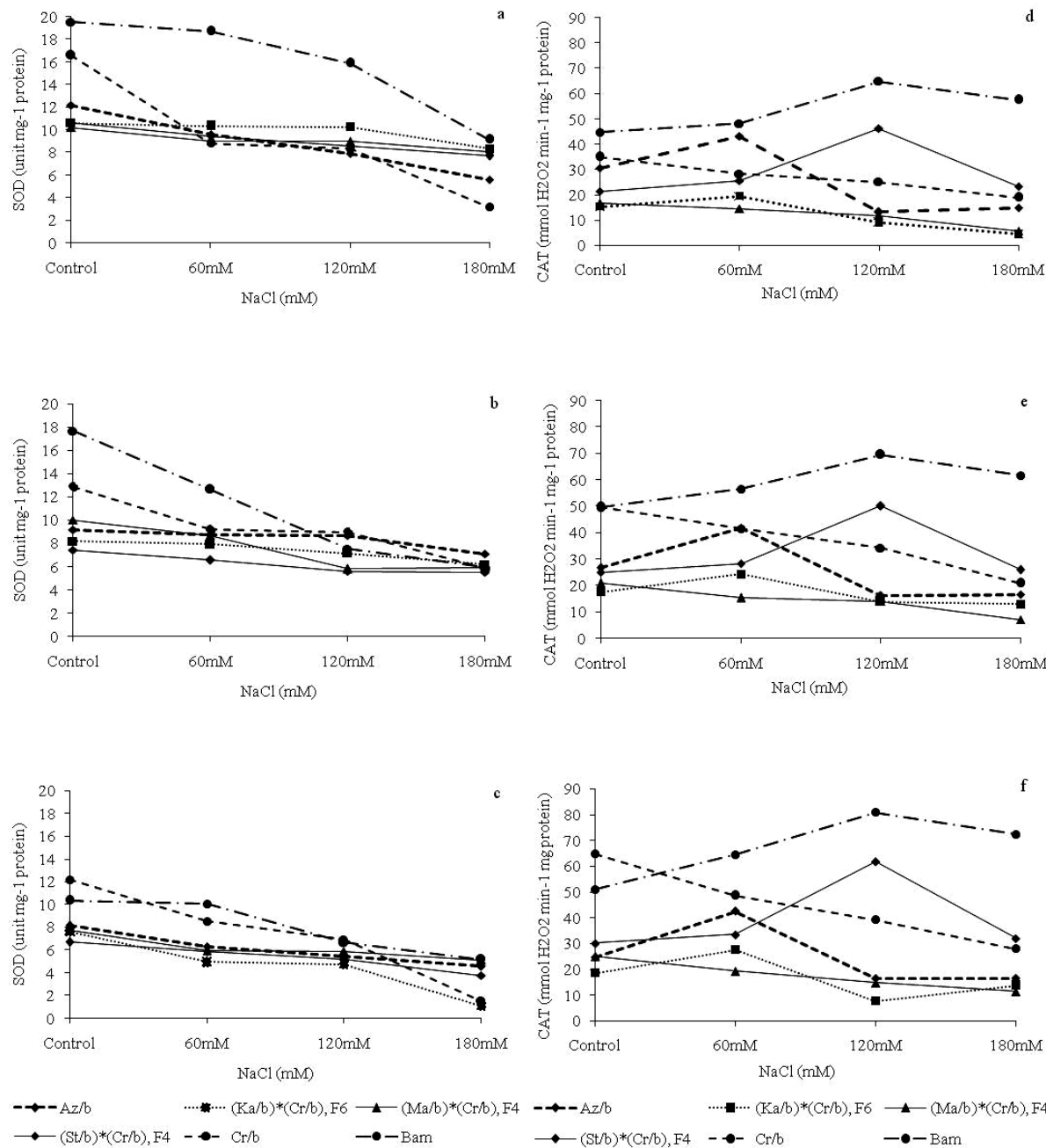

Fig 1. Effect of various salinity concentrations on SOD activity (U mg ${ }^{-1}$ protein) after (a) $48 \mathrm{~h}$ (b) one week (c) one month of salinity stress initiation and CAT activity ( $m$ mol $\mathrm{H}_{2} \mathrm{O}_{2} \mathrm{~min}^{-1} \mathrm{mg}^{-1}$ protein) after (d) $48 \mathrm{~h}$ (e) one week (f) one month of salinity stress initiation in tritipyrum lines and wheat cultivar Bam. Data are Mean \pm SE. Values are significantly different at $P \leq 0.05$.

Table 2. Abbreviation, ploidy level and genomic constitution of primary tritipyrum lines and wheat cultivars in the present study

\begin{tabular}{lccc}
\hline Genotypes & Abbreviation & Ploidy & Genome \\
\hline Wheat cultivar & & & \\
T.aestivum cv. Bam & Bam & $6 \mathrm{X}$ & AABBDD \\
Tritipyrum lines & & & \\
(Karim/Th. Bessarabicum $) *($ Creso/ Th. Bessarabicum $) \mathrm{F}_{6}$ & $(\mathrm{Ka} / \mathrm{b}) *(\mathrm{Cr} / \mathrm{b}), \mathrm{F}_{6}$ & $6 \mathrm{X}$ & $\mathrm{AABBE}^{\mathrm{b}} \mathrm{E}^{\mathrm{b}}$ \\
Creso/ Th. Bessarabicum & $\mathrm{Cr} / \mathrm{b}$ & $6 \mathrm{X}$ & $\mathrm{AABBE}^{\mathrm{b}} \mathrm{E}^{\mathrm{b}}$ \\
Aziziah/ Th. Bessarabicum & $\mathrm{Az} / \mathrm{b}$ & $6 \mathrm{X}$ & $\mathrm{AABBE}^{\mathrm{b}} \mathrm{E}^{\mathrm{b}}$ \\
\hline
\end{tabular}

Az/b exhibited higher MDA content than $(\mathrm{Ka} / \mathrm{b}) *(\mathrm{Cr} / \mathrm{b}), \mathrm{F}_{6}$ at all growth stages and salinity levels, but the reduction of MDA at low salinity level in Az/b was more than $(\mathrm{Ka} / \mathrm{b}) *(\mathrm{Cr} / \mathrm{b}), \quad \mathrm{F}_{6}$ and lipid peroxidation rate in $(\mathrm{Ka} / \mathrm{b}) *(\mathrm{Cr} / \mathrm{b}), \mathrm{F}_{6}$ was higher than that of $\mathrm{Az} / \mathrm{b}$ at $180 \mathrm{mM}$ $\mathrm{NaCl}$ (Fig. 3). MDA content of these genotypes showed a significant age-dependent increase, too (Fig. 3).

Wheat cultivar Bam and $\mathrm{Cr} / \mathrm{b}$ showed a pattern of MDA content that was different from that of $\mathrm{Az} / \mathrm{b}$ and $(\mathrm{Ka} / \mathrm{b})^{*}(\mathrm{Cr} / \mathrm{b}), \mathrm{F}_{6}$ (Fig. 5). There was both age- and salinitydependent increase in MDA content in these genotypes. MDA accumulation was lower in $\mathrm{Cr} / \mathrm{b}$ than in wheat cultivar Bam, indicating lower lipid peroxidation due to salinity stress
(Fig. 3). Az/b and $(\mathrm{Ka} / \mathrm{b}) *(\mathrm{Cr} / \mathrm{b}), \mathrm{F}_{6}$ had the lowest and wheat cultivar Bam and $\mathrm{Cr} / \mathrm{b}$ had the highest MDA content (Fig. 3).

\section{Factors affecting salinity tolerance in genotypes}

To analysis the similar and different characteristics of genotypes, to appraise the pattern of variation and to compare physiological mechanisms involved in increasing salinity resistance of tritipyrum lines and wheat, principal component analysis (PCA) was carried out using measured physiological parameters (Fig. 4). In two-dimensional graph of PCA, the cosine of the angle between two traits showed the correlation coefficient between them $\left(r=\cos 180^{\circ}=-1, \cos 0^{\circ}=1\right.$ and $\cos$ $90^{\circ}=0$ ). Carbohydrate content, POX, Chl $a$ and $\mathrm{CHl} b$ 

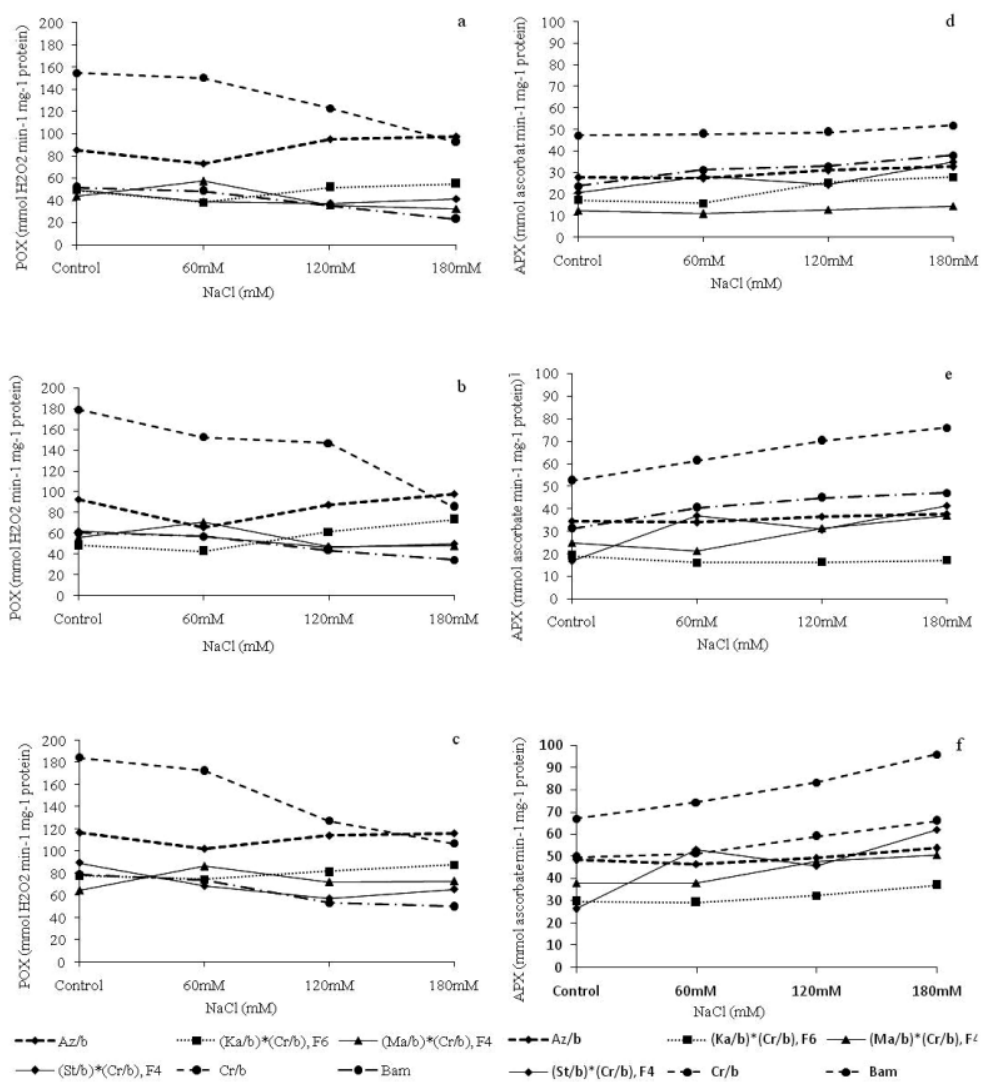

Fig 2. Effect of various salinity concentrations on POX activity (mmol $\mathrm{H}_{2} \mathrm{O}_{2} \mathrm{~min}^{-1} \mathrm{mg}^{-1}$ protein) after (a) $48 \mathrm{~h}$ (b) one week (c) one month of salinity stress initiation and APX activity (mmol $\mathrm{H}_{2} \mathrm{O}_{2} \mathrm{~min}^{-1} \mathrm{mg}^{-1}$ protein) after (d) $48 \mathrm{~h}$ (e) one week (f) one month of salinity stress initiation in tritipyrum lines and wheat cultivar Bam. Data are Mean \pm SE. Values are significantly different at $P \leq 0.05$.

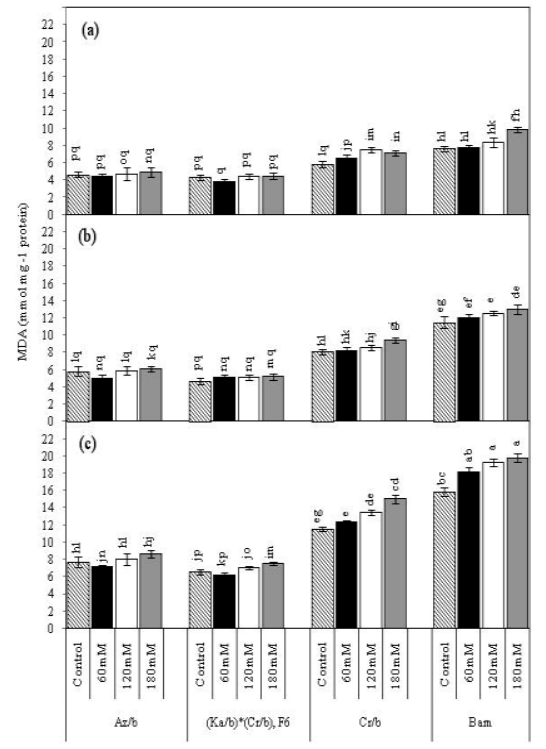

Fig 3. Effect of various salinity concentrations on MDA content ( $\mathrm{nmol} \mathrm{mg}{ }^{-1}$ protein) in tritipyrum lines and wheat cultivar Bam after (a) $48 \mathrm{~h}$ (b) one week (c) one month of salinity stress initiation. Data are Mean \pm SE. Values are significantly different at $P \leq 0.05$. 


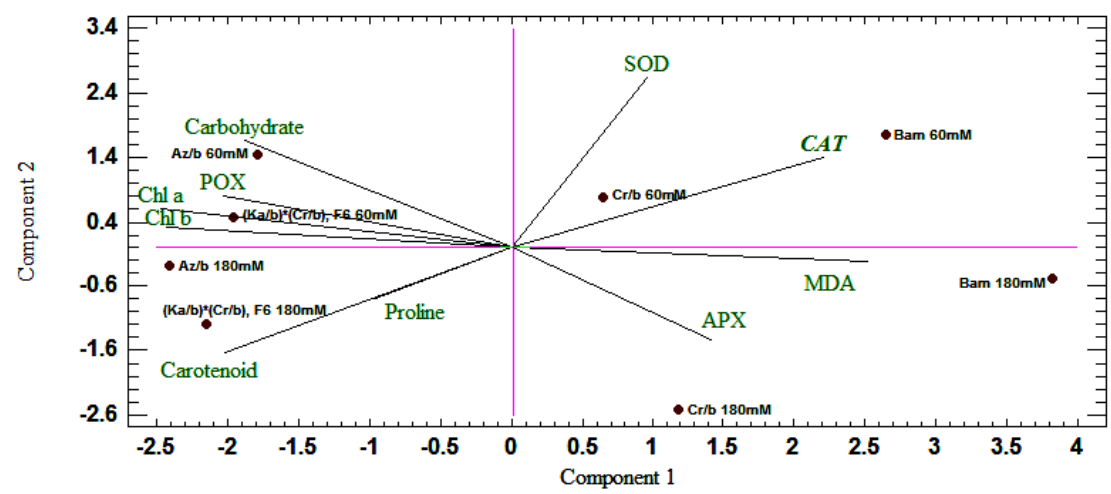

Fig 4. Biplot representation of the results of principal component analysis (PCA) based on measured characteristics of primary tritipyrum lines and wheat cultivar Bam during salinity stress. Genotypes names are beside the red point and the traits are made clear in uppercase letters. APX: Ascorbate peroxidase, MDA: Malondialdehyde, CAT: Catalase, SOD: Superoxide dismutase, POX: Peroxidase, Chl a: Chlorophyll $a$, Chl b: Chlorophyll $b$.

content were located in the same quadrant and it was found that they were positively correlated to each other. Furthermore, proline and carotenoid content were located in another quadrant and they had positive correlation to each other, too (Fig. 4). All of the mentioned traits in these quadrants were related to the osmotic adjustment and photosynthetic pigments and were negatively correlated to MDA content. Considering the fact that two-dimensional graph of PCA can help improve understanding of the relationship among genotypes and their measured characteristics, the negative relations of these traits with MDA showed their positive effect on the performance of genotypes in these quadrants $(\mathrm{Az} / \mathrm{b},(\mathrm{Ka} / \mathrm{b}) *(\mathrm{Cr} / \mathrm{b}), \mathrm{F} 6)$ under salinity conditions. SOD, CAT and APX were located in other quadrants. They had a positive correlation with each other and with MDA. It can show their negative effect on the performance of genotypes under salinity.

\section{Discussion}

Plants use various strategies to cope with the deleterious effects of salinity stress (Munns and Tester, 2008). Chlorophyll pigments have been reported as one of the parameters of salt tolerance in crop plants (Munns et al., 2006). The results of this study showed that wheat cultivar Bam exhibited lower chlorophyll content than tritipyrum lines under salinity treatment at three growth stages (Table 1). Salt stress caused an increase in Chl $a$ of tritipyrum lines but a decrease in Chl $a$ of wheat cultivar (Table 1). Higher amount of chlorophyll pigments in tritipyrum lines may be related to their higher membrane stability compared with that of wheat cultivar Bam under salinity stress (Munns et al., 2006). Salt tolerant genotypes are more capable than salt sensitive ones in maintaining chlorophyll pigments (Suriyan et al., 2009). Protecting chlorophyll synthesis against oxidative damage was reported to be an important response of wheat under salinity stress (Khatkar and Kuhad, 2000). Subtractive effect of salinity on chlorophyll pigments might be related to chlorophyll degradation (Santos, 2004) by proteolysis enzymes and a decrease in their synthesis (Khan, 2003). Moreover, the carotenoid content of tritipyrum lines was higher than that of wheat cultivar Bam. Higher value of carotenoids in salt tolerant genotypes was reported in other plants (Kholova et al., 2010). Higher carotenoid in tritipyrum lines may have an important role against ROS under salinity stress. Proline accumulation reduces cell injury by providing a favorable osmotic potential at cellular level, ROS scavenging and accompanying salt stress signaling (Mohanty and Matysik, 2001; Jacobs et al., 2003). Proline accumulation was higher in $\mathrm{Az} / \mathrm{b}$ and $(\mathrm{Ka} / \mathrm{b})^{*}(\mathrm{Cr} / \mathrm{b}), \mathrm{F}_{6}$ than in wheat cultivar Bam and $\mathrm{Cr} / \mathrm{b}$; so, increased proline content might be correlated with improved capacity of salinity tolerance. On the one hand, this is in contrary with the findings of some researchers who concluded that proline had either weak or no contribution to increased salt tolerance (Demiral and Türkan, 2005). Accumulation of soluble carbohydrate was reported as a defense mechanism to do osmotic adjustment and protect biomolecules during salinity stress (Nemati et al., 2011), but this finding was not conclusive. In this study, tritipyrum lines contained more carbohydrate than wheat cultivar Bam (Table 1). It might introduce carbohydrate as an agent that was responsible for higher salt tolerance of tritipyrum lines. The results were consistent with findings that reported higher accumulation of carbohydrate in salinity tolerant wheat genotypes compared with salt sensitive ones (Kerepesi and Galiba, 2000). ROS generation has injurious influence on membrane lipid and vital macromolecules like protein and DNA and causes cell damage or death (Mittler, 2002; Ashraf and Harris, 2004). Therefore, scavenging of ROS is necessary to provide physiological insight about increased salinity tolerance by breeding programs (Shao et al., 2007). In spite of the fact that tritipyrum lines salt tolerance was higher than wheat cultivar Bam, the amount of SOD activity and its reduction by salinity stress and age in wheat cultivar Bam was higher than that of tritipyrum lines except for $\mathrm{Cr} / \mathrm{b}$ (Fig. 1). This result could be connected with higher salinity resistance, and/or the use of another mechanism for detoxification of superoxide by tritipyrum lines. Lower changes in SOD activity of tritipyrum lines in comparison with those in wheat cultivar, especially at $60 \mathrm{mM} \mathrm{NaCl}$, might show the greater capacity of tritipyrum lines to maintain SOD activity. Usually, less amount of SOD or reduction in its activity by salinity stress was observed in salt sensitive genotypes (Seckin et al., 2010). Of course, contrary findings were reported by other researchers (Benavídes et al., 2000). CAT and POD detoxify $\mathrm{H}_{2} \mathrm{O}_{2}$ to $\mathrm{H}_{2} \mathrm{O}$ and $\mathrm{O}_{2}$ and protect cells against antioxidative damage (Ashraf, 2009). In our study, CAT activity of wheat cultivar Bam was higher than that of tritipyrum lines (Fig. 1). Significant increase in CAT activity at $60 \mathrm{mM} \mathrm{NaCl}$ might be related to better protection against $\mathrm{H}_{2} \mathrm{O}_{2}$ (Fig. 2). In $\mathrm{Cr} / \mathrm{b}$, increased salinity caused reduction in CAT activity, while wheat cultivar showed reverse trend (Fig. 1). It has been reported that salt tolerant plants have higher CAT activity than sensitive ones (Sairam et al., 2002). 
In the present study, the lowest amount of POX activity in $\mathrm{Az} / \mathrm{b}$ and $(\mathrm{Ka} / \mathrm{b})^{*}(\mathrm{Cr} / \mathrm{b}), \mathrm{F} 6$ was observed at $60 \mathrm{mM} \mathrm{NaCl}$ treatment (Fig. 2). POX activity of $\mathrm{Cr} / \mathrm{b}$ and wheat cultivar Bam decreased considerably by salinity stress (Fig. 2). POX activity and its changes by salinity in wheat cultivar Bam were higher than those of tritipyrum lines, except for $\mathrm{Cr} / \mathrm{b}$. Increasing POX activity by salinity stress was reported in various plants (Lee et al., 2001; Seckin et al., 2010). Although, some reports showed that salt tolerant genotypes had higher POX activity than sensitive one (Meloni et al., 2003), other experiments showed contrary findings (Demiral and Türkan, 2005).

APX, as a major and key enzyme, protects plants against antioxidant stress by scavenging $\mathrm{H}_{2} \mathrm{O}_{2}$ via ascorbate glutathione pathway (Asada, 2006). In the present study, growth and salinity caused changes in APX activity in all used genotypes (Fig. 2). The level of APX activity in tritipyrum lines except for $\mathrm{Cr} / \mathrm{b}$ was significantly lower than that of wheat cultivar Bam (Fig. 2). Different responses of APX activity against salinity was observed by researchers (Sairam and Srivatava, 2002; Sreenivasulu et al., 2000). It was reported that APX activity of salt tolerant genotypes is higher than that of salt sensitive ones (Nazar et al., 2011; Stepien and Klobus, 2005).

Having compared the $\mathrm{H}_{2} \mathrm{O}_{2}$ scavenging enzymes activity, it was observed that POX was more active than APX and CAT in scavenging $\mathrm{H}_{2} \mathrm{O}_{2}$ and could be characterized as a main evaluated $\mathrm{H}_{2} \mathrm{O}_{2}$ scavenging enzyme that contributed to more salt tolerance in studied genotypes. Some researchers reported that POX had more important role in scavenging $\mathrm{H}_{2} \mathrm{O}_{2}$ compared with other $\mathrm{H}_{2} \mathrm{O}_{2}$ detoxifying enzymes (Khedr et al., 2003)

At cellular level, malondialdehyde, a product of unsaturated lipid peroxidation of biomembranes, has been suggested as a reliable and effective indicator in salt-induced oxidative damage to cell membranes. Also, the negative effect of salinity stress on lipid peroxidation has been reported (Vaidyanathan et al., 2003; de Azevedo Neto et al., 2006). Maximum MDA was observed in wheat cultivar Bam, followed by $\mathrm{Cr} / \mathrm{b}$ and other titipyrum lines (Fig. 3). The lower MDA of tritipyrum lines at $60 \mathrm{mM}$ (Fig. 3) can explain their better protection against antioxidant damage and higher efficiency of enzymatic antioxidant defense system or higher compartmentation of salt ions in vacuole at these salinity levels.

The lower MDA in tritipyrum lines, especially in Az/b and $(\mathrm{Ka} / \mathrm{b}) *(\mathrm{Cr} / \mathrm{b}), \mathrm{F}_{6}$, implied that they are more secured than salt tolerant wheat cultivar Bam against oxidative damage; so, according to the negative relations between photosynthetic pigments and compatible solutes with MDA (Fig. 3), it was concluded that these traits might be involved in those tritipyrum lines that are more salt tolerant than wheat. However, the positive relations between measured enzymes and MDA can be related to the fact that they cannot be protective factors against deleterious effects of salinity in tritipyrum lines and/or their effect on protection of tritipyrum lines against salinity stress was lower than organic solutes and photosynthetic pigments.

It was reported that tritipyrum lines had different salinity resistance thresholds (Kamyab et al., 2016). Generally, the results revealed different used mechanisms and responses to salinity stress of tritipyrum lines in comparison with wheat cultivar Bam. Higher protection capacity of tritipyrum lines against salinity in comparisom with that of wheat cultivar Bam was exhibited by a lower MDA level. The differences were related to not only the variation of genotypes but also the intensity and duration of salinity treatment.
Although $\mathrm{Cr} / \mathrm{b}$ and wheat cultivar Bam had more enzymes activity than the other tritipyrum lines, their lipid peroxidation and membrane cell injury were more than other tritipyrum lines. These results suggested that ROS scavenging system in $\mathrm{Cr} / \mathrm{b}$ and wheat cultivar Bam might not be sufficient to eliminate the deleterious effect of salinity compared with other used tritipyrum lines and/or maybe, other mechanisms were involved in higher resistance of tritipyrum lines against salinity stress. Moreover, by investigation of photosynthetic pigments, proline, carbohydrate and the level of antioxidant enzymes, it could be concluded that tritipyrum lines has experienced less oxidative damage than wheat cultivar Bam during salinity stress or might have employed non enzymatic solution to deal with salinity stress. They may use compatible solutes for osmotic adjustment, carotenoids for quenching singlet oxygen and chlorophyll pigments for protecting capacity of photosynthesis to deal with salinity stress.

\section{Materials and methods}

\section{Plant material and growth condition}

Seeds of three tritipyrum lines including $(\mathrm{Ka} / \mathrm{b}) *(\mathrm{Cr} / \mathrm{b}), \mathrm{F}_{6}$ and $\mathrm{Az} / \mathrm{b}$ (as salt tolerant tritipyrum lines), $\mathrm{Cr} / \mathrm{b}$ (as a salt sensitive tritipyrum line) and T.aestivum cv. Bam (a salt tolerant wheat cultivar) were used based on findings of other studies carried out on their salt tolerance (Kamyab et al., 2016) (Table 2). Seeds with similar shape and weight were sown in seedling growing trays $(7 \mathrm{~cm}$ deep cells with a diameter of $2 \mathrm{~cm}$ ), the trays were filled with sand, soil and manure $(2: 1: 1)$. In order to be vernalized, seedlings were transferred out of the greenhouse for 6 weeks and exposed to temperature below $8^{\circ} \mathrm{C}$. At $3^{\text {rd }}$ leaf stage, healthy seedlings similar in shape and size were selected from growing trays and transferred to planting boxes $(43 \times 34 \times 25 \mathrm{~cm})$ that contained washed sand in a glasshouse with temperature of $25^{\circ} \mathrm{C} / 20^{\circ} \mathrm{C}$ over day/night and natural light in a hydroponic culture system. Four salinity levels of $0,60,120$ and $180 \mathrm{mM}$ were applied through irrigation after $4^{\text {th }}$ leaf stage. The seedlings were irrigated with half- strength Hoagland solution (Hoagland, 1950) for three days and then irrigated with fullstrength Hoagland nutrient solution (Hoagland, 1950). To apply salt treatments, $\mathrm{NaCl}$ was added in 3 steps by $60 \mathrm{mM} /$ day to reach the intended salinity levels, i.e. 0 (as control), 60, 120 and $180 \mathrm{mM} \mathrm{NaCl}$. 48hours, one week and one month after starting the salt treatment, flag leaves were harvested and frozen in liquid nitrogen and kept in a freezer $\left(-80^{\circ} \mathrm{C}\right)$ for analyses.

\section{Chlorophyll and carotenoid measurement}

To measure chlorophyll pigments and carotenoids, Lichtentaler method (1987) was applied. Leaf tissue was ground in liquid nitrogen and mixed with $80 \%$ acetone. The resulting solution was centrifuged and its absorption of the supernatant was read with spectrophotometer at wavelengths of 647, 664 and 470nm. The chlorophyll $a$ and $b$ and carotenoid were calculated by the following equations:

$$
C h l_{b}=21.21 A_{647}-5.1 A_{664}
$$$$
C h l_{a}=12.25 A_{664}-2.79 A_{647}
$$

Carotenoid $=(1000 A 470-1.8$ chla -85.02 chlb $) / 198$

Where $\mathrm{A}_{647}, \mathrm{~A}_{664}$ and $\mathrm{A}_{470}$ are absorbances at 647, 664 and $470 \mathrm{~nm}$ wave lengths, respectively. $\mathrm{Chl}_{\mathrm{a}}$ is chlorophyll $a, \mathrm{Chl}$ $\mathrm{b}$ is chlorophyll $b$, and $\mathrm{Chl}_{\mathrm{T}}$ is the total chlorophyll. 


\section{Carbohydrate content of flag leaf tissue}

Carbohydrate content was evaluated calorimetrically by phenol-sulfuric acid reagent method (Dubois et al., 1956) and its concentration was determined using standard curve as $\mathrm{mg} / \mathrm{g}$ fresh weight of sample.

\section{Proline content of flag leaf tissue}

Frozen leaf tissue was ground in liquid nitrogen. Proline was extracted with $10 \mathrm{ml} 3 \%(\mathrm{w} / \mathrm{v})$ sulfosalicylic acid. After centrifugation, the supernatant was used for determination of proline content, as described by Bates et al., (1973). Proline concentration was determined using standard curve as $\mu \mathrm{g} / \mathrm{ml}$ and calculated on fresh weight basis.

\section{Antioxidant enzymes activity assays}

\section{Enzyme extraction}

For enzyme extraction, the flag leaf samples $(500 \mathrm{mg})$ were ground and homogenized with $5 \mathrm{ml}$ of ice-cold $50 \mathrm{mM}$ potassium phosphate buffer ( $\mathrm{pH} 7.0$ ) containing $0.1 \mathrm{mM}$ of EDTA (Dhindsa, 1981). The whole extraction procedure was carried out at $4^{\circ} \mathrm{C}$. The homogenate was centrifuged at $4^{\circ} \mathrm{C}$ by refrigerated centrifuge. After centrifugation, the supernatant fraction was collected and used for determination of antioxidant enzyme activity and lipid peroxidation.

\section{Determination of enzymes activity}

According to Beauchamp and Fridovich (1971), Superoxide dismutase (SOD; EC 1. 15. 1. 1) was measured by spectrophotometer based on the inhabition of photochemical reduction of nitro-blue tetrazolium (NBT) at $560 \mathrm{~nm}$. One unit of SOD enzyme activity was defined as the amount of enzyme required to inhibit 50\% NBT photo reduction. The results were expressed as units $/ \mathrm{mg}^{-1}$ protein.

Catalase activity (CAT; EC 1. 11. 1. 6) was determined by Chance and Maehly's method (1955). CAT activity was assayed as changes in absorbance at $240 \mathrm{~nm}$ as $\mathrm{H}_{2} \mathrm{O}_{2}(\varepsilon: 39.4$ $\mathrm{mM}^{-1} \mathrm{~cm}^{-1}$ ) was consuming. CAT activity values are given in $\mu$ mol $\mathrm{H}_{2} \mathrm{O}_{2}$ consumed min $^{-1} \mathrm{mg}^{-1}$ protein.

Peroxidase (POX; EC. 1. 11. 1. 7) activity was measured according to Abeles and Biles method (1991). POD activity was measured by the $\mathrm{H}_{2} \mathrm{O}_{2}$-dependent oxidation of benzidine at $470 \mathrm{~nm}$. A unit of peroxidase activity was defined as mmol $\mathrm{ml}^{-1} \quad \mathrm{H}_{2} \mathrm{O}_{2}$ decomposed per minute (extinction coefficient $\left.26.6 \mathrm{mM}^{-1} \mathrm{~cm}^{-1}\right)$. The specific enzymes activity for POX was evaluated as $\mu \mathrm{mol} \mathrm{H}_{2} \mathrm{O}_{2} \mathrm{~min}^{-1} \mathrm{mg}^{-1}$ protein.

Ascorbate peroxidase (APX, EC 1. 11. 1. 11) activity was assayed spectrophotometrically according to Nakano and Asada's method (1981). APX activity was assayed by ascorbate oxidation at $290 \mathrm{~nm}$ for $1 \mathrm{~min}$. Enzyme activity was qualified using the extinction coefficient for ascorbate $(\varepsilon$ : $\left.2.8 \mathrm{mM}^{-1} \mathrm{~cm}^{-1}\right)$. APX activity was defined as mmol ascorbate $\mathrm{min}^{-1} \mathrm{mg}^{-1}$ protein.

\section{Lipid peroxidation}

Heath and Parcker (1968) method was used for the evaluation of MDA that was used as an indicator of lipid peroxidation and oxidative damage. The absorbance of reaction mixture was read at 532 and $600 \mathrm{~nm}$. MDA content was identified as mmol MDA g ${ }^{-1} \mathrm{FW}\left(\varepsilon: 155 \mathrm{mM}^{-1} \mathrm{~cm}^{-1}\right)$.

\section{Experimental design and statistical analysis}

Experimental design was a split plot in completely randomized design with three replications. Simple statistical analysis including mean comparison and standard error were conducted by SPSS (Ver. 16.0, SPSS, Chicago, IL, USA). Mean comparisons were calculated using Tukey's test at 5\% probability level. Principal component analysis (PCA) was used to obtain a multivariate view of collected variables and data. Principal component analysis (PCA) were carried out using Statgraphics Centurion oftware, version 16. Charts were drawn using Excel software.

\section{Conclusion}

Tritipyrum lines had different thresholds to salinity stress. Furthermore, they performed better in low salinity than in no salinity condition. The results indicated that salt tolerance in tritipyrum lines cannot be defined just by one criterion and various regulatory mechanisms were involved. In tritipyrum lines, compatible solutes and photosynthetic pigments played more important roles than enzymes in the protection of plants against salinity stress. Increased their enzyme activity with increased growth and development suggested that these genotypes were flexible in terms of resistance to salinity stress. Generally, according to the strong response of tritipyrum lines, especially Az/b, to salinity, it is recommended to further study on this plant and examine its use in salinity studies including improved wheat resistance to salinity. Of course, understanding the mechanisms of resistance to salt stress in tritipyrum lines needs more extensive, deeper and comprehensive studies in various physiological and molecular areas.

\section{Acknowledgments}

The authors would like to express their appreciation to Ferdowsi University of Mashhad, Iran, for providing funds of this research. They would like to extend their sincere gratitude to their colleagues, Dr. Shahsavand, who provided the seeds of tritipyrum lines.

\section{References}

Abeles FB, Biles CL (1991) Characterization of peroxidase in lignifying peach fruit endocarp. Plant Physiol. 95: 269-273.

Ahmad P, Jaleel CA, Salem MA, Nabi G, Sharma, S (2010) Roles of enzymatic and nonenzymatic antioxidants in plants during abiotic stress. Crit Rev Biotechnol. 30: 161175.

Ahmad P, Kumar A, Ashraf M, Akram NA (2012) Saltinduced changes in photosynthetic activity and oxidative defense system of three cultivars of mustard (brassica juncea 1.). Afr J Biotechnol. 11: 2694-2703.

Apel K, Hirt H (2004) Reactive oxygen species: Metabolism, oxidative stress, and signal transduction. Annu Rev Plant Biol. 55: 373-399.

Ashraf M (2009) Biotechnological approach of improving plant salt tolerance using antioxidants as markers. Biotechnol Adv. 27: 84-93.

Asada K (2006) Production and scavenging of reactive oxygen species in chloroplasts and their functions. Plant Physiol. 141:391-396.

Ashraf M, Harris P (2004) Potential biochemical indicators of salinity tolerance in plants. Plant Sci. 166: 3-16.

Ashraf M, Harris P (2013) Photosynthesis under stressful environments: An overview. Potosynthetica. 51: 163-190. 
Bates L, Waldren R, Teare I (1973) Rapid determination of free proline for water-stress studies. Plant soil. 39: 205-207.

Beauchamp C, Fridovich I (1971) Superoxide dismutase: improved assays and assay applicable to acrylamide gels. Anal Biochem. 44: 276-286.

Benavídes MP, Marconi PL, Gallego SM, Cmba ME, Tomaro ML (2000) Relationship between antioxidant defence systems and salt tolerance in solanum tuberosum. Funct Plant Biol. 27: 273-278.

Chance M, Maehly AC (1955) Assay of catalases and peroxidases. Methods Enzymol. 2: 764-817.

De Azevedo Neto AD, Prisco JT, Enéas-Filho J, de Abreu CEB, Gomes-Filho E (2006) Effect of salt stress on antioxidative enzymes and lipid peroxidation in leaves and roots of salt-tolerant and salt-sensitive maize genotypes. Environ Exp Bot. 56: 87-94.

De Lacerda CF, Cambraia J, Oliva MA, Ruiz HA, Prisco JTN (2003) Solute accumulation and distribution during shoot and leaf development in two sorghum genotypes under salt stress. Environ Exp Bot. 49: 107-120.

Demiral T, Türkan I (2005) Comparative lipid peroxidation, antioxidant defense systems and proline content in roots of two rice cultivars differing in salt tolerance. Environ Exp Bot. 53: 247-257.

Dhindsa RS, Plumb-Dhindsa P, Throne TA (1981) Leaf senescence: correlated with increased levels of membrane permeability and lipid peroxidation and decreased levels of superoxide dismutase and catalase. J Exp Bot. 32: 93-101.

Dubois M, Gilles K, Hamilton J, Roberts PA, Smith F (1956) Phenol sulphuric acid method for carbohydrate determination. Ann Chem. 28: 350 $\square 359$.

Hasegawa PM, Bressan RA, Zhu JK, Bohnert HJ (2000) Plant cellular and molecular responses to high salinity. Annu Rev Plant Biol. 51: 463-499.

Heath RL, Packer I (1968) Photoperoxidation in isolated chloroplst I, kinetics and stochiometry of fatty acid peroxidation. Arch Biochem Biophys. 125: 189-198.

Hoagland DR, Arnon D I (1950) The water-culture method for growing plants without soil. Circular. Calif AES Bull. 347: 1-32.

Jacobs M, Angenon G, Hermans C, Thu TT, Roosens NH (2003) Proline accumulation and $\delta$ 1-pyrroline-5carboxylate synthetase gene properties in three rice cultivars differing in salinity and drought tolerance. Plant Sci.165: 1059-1068.

Kamyab M, Kafi M, Shahsavand H, Goldani M, Shokouhifar F (2016) Exploring ion homeostasis and mechanism of salinity tolerance in primary tritipyrum lines (wheatx thinopyrum bessarabicum) in the presence of salinity. Aust J Crop Sci. 10: 911-919.

Kerepesi I, Galiba G (2000) Osmotic and salt stress-induced alteration in soluble carbohydrate content in wheat seedlings. Crop Sci. 40: 482-487.

Khan M., Shirazi M., Khan M.A, Mujtaba S, Islam E, Mumtaz S, Shereen A, Ansari R, Ashraf MY (2009) Role of proline, $\mathrm{k} / \mathrm{na}$ ratio and chlorophyll content in salt tolerance of wheat (triticum aestivum 1.). Pak J Bot. 41: 633-638.

Khan N (2003) Nacl-inhibited chlorophyll synthesis and associated changes in ethylene evolution and antioxidative enzyme activities in wheat. Biol Plantarum. 47: 437-440.

Khatkar D, Kuhad M (2000) Short-term salinity induced changes in two wheat cultivars at different growth stages. Biol Plantarum. 43: 629-632.

Khedr AHA, Abbas MA, Wahid AAA, Quick WP, Abogadallah GM (2003) Proline induces the expression of saltstressresponsive proteins and may improve the adaptation of pancratium maritimum 1 to saltstress. J Exp Bot. 54: 2553-2562.

Kholova J, Sairam RK, Meena RC (2010) Osmolytes and metal ions accumulation, oxidative stress and antioxidant enzymes activity as determinants of salinity stress tolerance in maize genotypes. Acta Physiol Plant. 32: 477-486.

King I, Law C, Cant K, Orford S, Reader S, Miller T (1997) Tritipyrum, a potential new salttolerant cereal. Plant Breeding. 116: 127-132.

Kishor PK, Sangam S, Amrutha R, Laxmi PS, Naidu K, Rao K, Rao S, Reddy K, Theriappan P, Sreenivasulu N (2005) Regulation of proline biosynthesis, degradation, uptake and transport in higher plants: Its implications in plant growth and abiotic stress tolerance. Curr Sci. 88: 424-438.

Lee DH, Kim YS, Lee CB (2001) The inductive responses of the antioxidant enzymes by salt stress in the rice (oryza sativa 1.). J Plant Physiol. 158: 737-745.

Lichtenthaler HK (1987) Chlorophylls and carotenoids: pigments of photosynthetic biomembranes. Method Enzymol. 148: 350-382.

Matysik J, Bhalu B, Mohanty P (2002) Molecular mechanisms of quenching of reactive oxygen species by proline under stress in plants. Curr Sci India. 82: 525-532.

Meloni DA, Oliva MA, Martinez CA, Cambraia J (2003) Photosynthesis and activity of superoxide dismutase, peroxidase and glutathione reductase in cotton under salt stress. Environ Exp Bot. 49: 69-76.

Mittler R (2002) Oxidative stress, antioxidants and stress tolerance. Trends Plant Sci. 7: 405-410.

Mohanty P, Matysik J (2001) Effect of proline on the production of singlet oxygen. Amino Acids. 21:195-200.

Munns R, James RA, Läuchli A (2006) Approaches to increasing the salt tolerance of wheat and other cereals. J Exp Bot. 57: 1025-1043.

Munns R, Tester M (2008) Mechanisms of salinity tolerance. Annu Rev Plant Biol. 59: 651-681.

Nakano Y, Asada K (1981) Hydrogen peroxide is scavenged by ascorbate-specific peroxidases in spinach chloroplasts. Plant Cell Physiol. 22: 867-880.

Nazar R, Iqbal N, Syeed S, Khan NA (2011) Salicylic acid alleviates decreases in photosynthesis under salt stress by enhancing nitrogen and sulfur assimilation and antioxidant metabolism differentially in two mungbean cultivars. J Plant Physiol. 168: 807-815.

Nemati I, Moradi F, Gholizadeh S, Esmaeili M, Bihamta M (2011) The effect of salinity stress on ions and soluble sugars distribution in leaves, leaf sheaths and roots of rice (oryza sativa 1.) seedlings. Plant Soil Environ. 57: 26-33.

Parida AK, Das AB (2005) Salt tolerance and salinity effects on plants: A review. Ecotox Environ Safe. 60: 324-349.agi A (2004) Physiology and molecular biology of salinity stress tolerance in plants. Curr Sci India. 86: 407-421.

Sairam RK, Rao KV, Srivastava G (2002) Differential response of wheat genotypes to long term salinity stress in relation to oxidative stress, antioxidant activity and osmolyte concentration. Plant Sci. 163: 1037-1046.

Sairam R K, Srivastava GC (2002) Changes in antioxidant activity in sub-cellular fractions of tolerant and susceptible wheat genotypes in response to long term salt stress. Plant Sci. 142: 897-904.

Santos CV (2004) Regulation of chlorophyll biosynthesis and degradation by salt stress in sunflower leaves. Sci HorticAmsterdam. 103: 93-99.

Seckin B, Turkan I, Sekmen AH, Ozfidan C (2010) The role of antioxidant defense systems at differential salt tolerance of hordeum marinum huds.(sea barleygrass) and hordeum vulgare 1.(cultivated barley). Environ Exp Bot. 69: 76-85. 
Shao HB, Chu LY, Wu G, Zhang JH, Lu ZH, Hu YC (2007) Changes of some anti-oxidative physiological indices under soil water deficits among 10 wheat (triticum aestivum 1.) genotypes at tillering stage. Colloid Surface B. 54: 143149, 2007.

Sharma P, Jha AB, Dubey RS, Pessarakli M (2012) Reactive oxygen species, oxidative damage, and antioxidative defense mechanism in plants under stressful conditions. Journal of Botany. 2012: 1-26.

Stepien P, Klobus G (2005) Antioxidant defense in the leaves of C3 and C4 plants under salinity stress. Physiol Plantarum. 125: 31-40.

Sreenivasulu N., Grimm B., Wobus U, Weschke W (2000) Differential response of antioxidant compounds to salinity stress in salttolerant and salt-sensitive seedlings of fox-tail millet (Setaria italica). Physiol Plantarum. 109: 435-442.

Suriyan CU, Supaibulwattana K, Kirdmanee C (2009) Comparative effects of salt stress and extreme ph stress combined on glycinebetaine accumulation, photosynthetic abilities and growth characters of two rice genotypes. Rice Science. 16: 274-282.

Vaidyanathan H, Sivakumar P, Chakrabarty R, Thomas G (2003) Scavenging of reactive oxygen species in naclstressed rice (oryza sativa 1.) differential response in salttolerant and sensitive varieties. Plant Sci. 165: 1411-1418.

Wang ZQ, Yuan YZ, Ou JQ, Lin QH, Zhang CF (2007) Glutamine synthetase and glutamate dehydrogenase contribute differentially to proline accumulation in leaves of wheat (triticum aestivum) seedlings exposed to different salinity. J Plant Physiol. 164: 695-701.

Yokoi S, Bressan RA, Hasegawa PM (2002) Salt stress tolerance of plants. JIRCAS working report. 23: 25-33.

Zhu JK (2001) Plant salt tolerance. Trends Plant Sci. 6: 66$71,2001$. 